\title{
The Research of the Socio-Cultural Environment of Ancient Cities and its Ad's Promotion as One of the Sides of Dialogue of Cultures
}

\author{
Amurskaya $\mathrm{O}$. \\ Faculty of History and International Relations \\ RSU named for S.Yesenin \\ Ryazan, Russia \\ o.amurskaya@365.rsu.edu.ru
}

\author{
Nikolashina E. \\ Faculty of History and International Relations \\ RSU named for S.Yesenin \\ Ryazan, Russia \\ e.nikolashina@365.rsu.edu.ru
}

\begin{abstract}
Culture development in the current millennium is characterized by global world-over processes in socioeducational, economic and political spreres. Modern intensive development of information technologies and existing demand of the global society for the information give reasons for a new information culture formation. Advertising promotion of national cultures and ancient cities as manifistators of these cultures is determined by the system of values, norms and rules of behavior that are formed along with the development of the society. The problem of fruitful dialogue of ancient cities as representatives of different cultures and traditions is a strategic direction of the formation of the world order of the XXI century as an example of great importance for stability and peace in the world. New knowledge, development and implementation of educational programs, strengthening of academic cooperation with educational institutions of Russia helps to develop, disseminate and popularize the socio-cultural environment of ancient cities by means of scientific, educational and creative potential of the teaching and researching staff of Ryazan State University named for S. Yesenin.
\end{abstract}

Keywords-socio-cultural environment; ancient cities; dialogue of cultures; UNESCO chair; education; research.

\section{INTRODUCTION}

The XXI century is characterized mainly by mass world processes of political, economic and social globalization. This sociocultural dynamics and globalization are the issues widely discussed in the modern world especially under conditions of the quickly and constantly changing life and under the avalanche-like growth of information. Information today is a special tool for achieving different goals in various spheres. [1] We are to remember that each nation bears unique traditions and customs, that are transferred by different ways and means of communication. And the development of cultures is possible because of interaction between different nations and peoples.

Culture has many meanings. As a practical human activity, it is an inherent part of both individual and collective development, from the education of a single child to the finest artistic expression of entire peoples and nations. Closely related both to the achievements of the past (history) and of the future (innovation), culture suggests the capacity to survive as well as to adapt to change. It is the culmination of collective human intellectual achievement of a given society at a particular time. Culture also refers to the customs of a given society, especially as reflected in its social institutions and practices, including social and political organization and religion. In cities, culture materializes in the built environment (palaces, temples, opera houses, museums) and even parks, memorials, and marketplaces which in turn become visual symbols of local identity. [2]

Although in the human history we can find examples of existence of cultures being self-sufficient and practically not contacting with the outside world, it would be, nevertheless, a rare example, not a normal case. In fact, nearly each culture has an imprint of other cultures influencing it, mostly neighboring cultures, but, may be even to a greater extent, of the ones being the most developed and, due to this fact, more attractive from the viewpoint of exchanging experience, results and achievements. [3] Some specialists are sure in hostility of cultures. [4] Their opponents suppose that various cultures add value to each other. Modern intensive development of information technologies and existing demand of the global society for the information give reasons for a new information culture formation. [5] This information culture is an integral part of the national culture and is determined by the system of values, norms and rules of behavior that are formed along with the development of the society. It reflects the experience of nations, of the global society, that passed down from generation to generation and stored in the consciousness of every representative of this national society. [1]

In this regard it is necessary to acknowledge the role of traditional ancient cities in the process of transferring of the cultures of various nations through years. In Russian science the term "ancient city" is used for the cities that are over 500 years old. Modern specialists recognize the relevance of problems of preserving traditions and cultures, that are 
determined by the specific features of the development of culture in the history of the world space. To have the opportunity to create something new, we are to preserve that we have been having. It is obvious that the globalization is the most important factor of the world significant changes that brings into life many obvious advantages. [6] In this respect Ryazan State University named for S.A.Yesenin initiates the establishment of a UNESCO chair "The Research of the Socio-Cultural Environment of Ancient Cities". The main objective of the project states as formation and development of a common intellectual space for the identification, dissemination and exchange of research results in the field of legal and socio-ethical, historical, social and cultural foundations of the environment of ancient cities.

\section{LITERATURE REVIEW}

Globalization creates new forms of partnership and possible exchanges not only between individuals, but between societies, as well as cultures and civilizations, that are favorable for mutual understanding and peace. Ryazan, being an ancient city itself (the first written mention of the city dates to the early 13th century), organized of the First Forum of Ancient Cities, a global platform to discuss development and preservation of ancient towns and cities. It was held in August, 2018. This forum was the successful attempt to establish a kind of multicultural collaboration. During the Forum representatives of 14 countries were remembering old connections and set the new ones. It was settled that the ancient cities and towns of Russia and Europe have more in common than just medieval maps and history books. Concerns, challenges, possibilities and issues have much in common. Status of ancient settlement imposes lots of restrictions onto a town and its inhabitants, but at the same time it provides a lot of opportunities for development. The Forum served as a site for the leading international experts to have a constructive and fruitful discussion on the ways of preserving heritage from the past and embodying the inherited potential. As the issues under consideration are significant and burning the Forum received the status of a long-term project and the second Forum of Ancient Cities was held in Ryazan in 2019. The main objectives of the forum are development of multiethnic and multicultural collaboration, strengthening of interregional and international relations, the development of domestic and outbound tourism. The Forum was initiated by the Government of the Ryazan region under the partnership of UNESCO. RSU named for S.A. Yesenin, being the oldest educational and science centre in Ryazan region, made a proposal for the establishment of a UNESCO chair "The Research of the Socio-Cultural Environment of Ancient Cities" with reference to the relevance of the issue.

\section{RESEARCH METHODOLOGY}

Ryazan State University named for S. Yesenin is an institution of higher education which is over 100 years old (in 2019 the university will celebrate 104 anniversary). It is the oldest university in the region. The University consists of 10 institutes and faculties, which unite about 50 departments and research departments. Currently, the university has 9,500 students. The university offers Bachelor' Degree, Master's
Degree, postgraduate as well as additional professional education programs.

The university cooperates at the regional and global levels with universities and educational centers of several foreign countries. The University's international activity ensures its integration into the international university community, obtaining additional opportunities for accelerated development and competitive advantages. It is organized in accordance with the Charter of the University, the charters and the principles of activities of international associations, joined by RSU named for S.Yesenin, and bilateral agreements with foreign partner universities.

At the end of 2018, Ryazan State University named for S. Yesenin was given the status of a federal innovation platform "RSU named for S. Yesenin - educational center for innovative development of the social-humanitarian sphere of the region". The main tasks of the innovative educational project are: creation of conditions for the development of human capital and self-realization of the individual, provision of social support, formation of one of the largest centers of culture and tourism in Russia, protection of historical and cultural wealth etc.

RSU requestes for the establishment of UNESCO chair as of an interdisciplinary chair joining the research work of variety of the university departments and faculties: the Russian History Department, Department of World History and International Relations, Department of Foreign Languages, Department of Advertising and Sociocultural Communication, Faculty of History and International Relations; Department of Culturology, Faculty of Russian Philology and National Culture; Department of Physical Geography and Methods of Teaching Geography, Faculty of Geography and Natural Sciences; Department of Sociology, Faculty of Sociology and Government.

As the initiative is promising the proposal has received support from iniversities the world over: Germany, Spain, Cyprus, China, Japan, Republic of Abkhazia, Republic of Armenia, Republic of Belarus, as well as of Russian universities.

The research of the socio-cultural environment of ancient cities implies studying and exploring everyday issues, everyday life, lifestyle of the inhabitants of ancient cities in historical, cultural, archaeological, sociological aspects. Besides, it includes the processes of the accumulation, dissemination and popularization of the results.

The purpose of establishing a chair is to promote cooperation of international, national and regional subjects of socio-cultural and educational activities based on the development of advanced domestic and foreign experience of humanitarization of various spheres of life for the research of ancient cities in network and internetwork format.

Conditions for the formation and implementation of an integrated system of research are supposed to be created at the UNESCO chair. It is planned to develop modern educational technologies and teaching materials. Staff training and retraining as well as implementation of experimental work in the field of social communications, intercultural interaction 
heritage of their homeland and other territories. Many of them continue their research work while doing Master's Degree and postgraduate program. $[9,10,11]$

The proposed research is not an absolutely new studying. Professionals, academics and students of RSU named for S.Yesenin have been working on the problems of investigation, evaluation, inspection and reflection of the past of ancient cities, legal and socio-ethical, historical, social and cultural foundations of the environment. Civil society have always been interested in the history puzzles and culture traditions. Public authorities seek for decision in the past, while media find out mysteries and unusual aspects. According to that the results of the project are aimed primarily at the abovementioned public and professional groups.

The research and the results are claimed to be clear and visible through networks.

To cope with all the aims different activity types are worked out. To be able to investigate the settled problems comparative research in the field of law, culture, sociology and history is to be conducted. Effective channels of interaction between the countries and peoples with a rich historical past are being discussed to form. Besides, an educational and business platform with the involvement of leading Russian and international experts who deal with the themes of the development of the urban environment, history, tourism, cultural heritage and other relevant problems and tasks of the development of ancient cities in the modern world is being developed.

Among the other important activities that are required by the research we should mention:

- development and implementation of a set of measures aimed at involving various segments of the population and social groups in the research and development of the urban environment;

- development, within the framework of additional professional education, of short-term advanced training programs in increasing tourist attractiveness of ancient cities;

- holding various events (including youth events) related to issues on the chair's research theme (round tables, panel discussions, forums, symposia, conferences);

- holding public lectures by recognized experts on the research theme;

- active participation in the activities of the Commission of the Russian Federation for UNESCO.

\section{RESULTS}

All the methodological and organizational work, formation of the material-technical base, formation of criteria for evaluating lecturers' and students' activities, as well as finding new partners among foreign universities, lead to organized events, involving schoolchildren and teachers of educational institutions of secondary education from Ryazan, the Ryazan Region, constituent entities of the Russian Federation, and foreign partners. Monitoring scientific events within the framework and in relevance to the stated theme, attendance of competition enter RSU named for S.Yesenin and conduct serious research work on the study of historical and cultural environment of ancient cities is promising for development starting from the school stage. Over the past 15 years a local history competition "Ryazan Land. History. Monuments. People" has been successfully held in schools of the Ryazan 
globalized world. Conversely, when there is inter-ethnic tension in the society and, even more so, interethnic conflicts, then the dialogue between cultures is difficult, the interaction of cultures can be limited in the field of interethnic tension of these peoples, carriers of these cultures. This international relation is not a mere adaptation of a highle developed culture achievements by a younger or less developed one. It is something more deep, as the interaction of culture as a source of progress.

The problem of fruitful dialogue of ancient cities as representatives of different cultures and traditions is a strategic direction of the formation of the world order of the XXI century as an example of great importance for stability and peace in the world.

\section{References}

[1] Lipets E.Y., Serdyukova E.V., Agapova E.A. Dialogue of Cultures in the Context of Globalization: An Ethnic Aspect. European Research Studies Journal. Volume XXI, Special Issue 2, 2018. Pp. 369-376.

Dialogue of cultures, of nations, of cities is an integral part of the world-historical process. And in the age of increasing globalization it acquires a special urgency and responsibility at all levels of interaction - international, integration associations, state, non-state structures, individual persons. Modern society and contemporary science can be characterized by the constant growth of people's need for international and intercultural communication. The everincreasing growth of social tension, that is aggravated by economic and political instability in the world, leads, in its turn, to the growth of interethnic conflicts. [10] In this connection, there is a need of solving such an urgent problem as the problem of the culture communication, the problem of historical knowledge that involves the search for civilized forms and norms of communicative behavior of people in the field of intercultural relations

The interaction of cultures, the dialogue of ancient cities is a perfect basis for the development of international relations, the importance of which is so evident in the modern
[2] Dialogue on urban cultures: globalization and culture in an urbanizing world. World Urban Forum. Barcelona, 2004.

[3] Chumakov A.N. Culture in the Global World: Dialogue and Conflict. Age of Globalization, 2010. № 2.

[4] Danilevsky N. Russia and Europe. M., 1991.

[5] Nikolashina E.A. Dialogue of Culture in Foreign Languages Learning. Science and Education. Belgorod, 2018. Pp. 43-48.

[6] Chumakov A.N. Cultural and Civilizational Dialogue as a Way of Solving Problems in the Modern World. Вопросы философии. 2013. T. 1. C. 52 .

[7] Transforming our World: the 2030 Agenda for Sustainable Development.

[8] Medium-Term Strategy, 2014-2021. UNESCO. General Conference, 37th, 2013.

[9] Amurskaya O.I., Muravyova A.V. The Role of Brending in Education. Development Trends of Science and Education. Samara, 2018. Pp.30-32.

[10] Chumakov A.N. Culture in the Global World and Opportunities for Dialogue. Synthesis Philosophica. 2016. T. 62. № 2. C. 413-422. 